\title{
Analisis Kepatuhan Emiten Dalam Menerapkan Good Corporate Governance
}

\author{
Eka Lestari Hafqi Putri
}

Universitas Airlangga

Korespondensi: eka.lestarihp@ vokasi.unair.ac.id

Diserahkan: 15 Juli 2017, Direvisis: 11 Agustus 2017 Diterima: 9 September 2017

\begin{abstract}
All of the listed companies must obedient to the regulation of Indonesian stock exchange about good corporate governance, but actually there are still many violations. This study aims to analyze the obdience of listing companies against regulation about good corporate governance and explain effect of factorsin in influencing obdience. The analysis method used in this study is descriptive statistic analysis.The population in this study is 21 mining companies listed in Indonesian stock exchange in the period 2012-2014. The result showed that factors that affect the obdience of listing companies in applying good corporate governance is age, size, frequency of meeting the board of commisioners, corporate secretary, public share ownership, and timely financial statement reporting. While the factor composition of board of commissioner, number of audit committee, frequency of meeting the audit committee and CSR does not affect.

Keywords : Good Corporate Governance, Age, Size, The Board Of Commisioners, Corporate Secretary, Kepemilikan Saham Share Ownership, And Timely Financial Statement Reporting
\end{abstract}

\begin{abstract}
Abstrak
Seluruh emiten yang terdaftar dibursa diharuskan untuk memenuhi aturan terkait good corporate governance, namun ternyata masih banyak pelanggaran yang terjadi. Tujuan dilakukan penelitian ini adalah untuk menganalisis kepatuhan emiten terhadap aturan good corporate governance dan faktor-faktor yang mempengaruhinya. Metode analisis yang digunakan dalam penelitian ini adalah analisis statistik deskriptif. Penelitian ini dilakukan pada 21 emiten pertambangan yang terdaftar di Bursa Efek Indonesia dalam kurun waktu tahun 2012 sampai tahun 2014. Hasil dari penelitian menunjukkan bahwa faktor-faktor yang mempengaruhi kepatuhan emiten dalam menerapkan good corporate governance adalah usia, size perusahaan, frekuensi rapat dewan komisaris, sekretaris perusahaan, kepemilikan saham oleh publik, dan ketepatan waktu pelaporan keuangan, sedangkan factorkomposisi dewan komisaris, jumlah komite audit, frekuensi rapat komite audit dan CSR tidak berpengaruh pada penerapan aturan good corporate governance.

Kata Kunci : Good Corporate Governance, Usia, Size, Dewan Komisaris, Sekretaris Perusahaan, Kepemilikan Saham Dan Ketepatan Waktu Pelaporan
\end{abstract}

\section{A. PENDAHULUAN}

Kepatuhan emiten terhadap peraturan yang ada di Bursa merupakan syarat mutlak yang diperlukan jika perusahaan memutuskan untuk go publik. Hal inilah yang menyebabkan banyak perusahaan yang enggan untuk masuk ke bursa, bahkan keluar dari bursa jika dirasa modal yang di targetkan telah mencukupi. Tinggi rendahnya harga saham itu dapat mempengaruhi keputusan para investor atau calon investor untuk membeli saham emiten (Mujati \& Meida, 2016). Berdasarkan data statistik pasar modal Otoritas Jasa Keuangan pertumbuhan jumlah anggota bursa pada tahun 2012-2014 mengalami pasang surut. Tahun 2012 terdapat 24 perusahaan baru yang tercatat di bursa kemudian terjadi peningkatan pada tahun 2013 sejumlah 30 perusahaan dan menurun pada tahun 2014 menjadi 23 perusahaan. Pasang surutnya jumlah anggota bursa dapat disebabkan oleh faktor makro suatu negara seperti kondisi pertumbuhan ekonomi, tingkat inflasi, suku bunga dll yang berpengaruh terhadap perusahaan dan ketatnya 
peraturan yang harus dipatuhi oleh emiten ketika menjadi anggota bursa. Peraturan tersebut meliputi peraturan pelaporan keuangan perusahaan, prinsip keterbukan emiten hingga larangan adanya insider trading. Peraturan-peraturan tersebut harus terpenuhi agar emiten tidak terkena sanksi dari Otoritas bursa.

Bapepam-LK merupakan lembaga yang ditunjuk oleh pemerintah untuk mengawasi dan mengatur bursa efek indonesia. Fungsi bapepam juga meliputi pembuatan peraturan dibidang pasar modal. Pembentukan bapepam sendiri oleh pemerintah untuk mewujudkan tata kelola pada industri pasar modal di indonesia yaitu bursa, sehingga kegiatan bursa lebih efisien, transparan serta mampu menciptakan industri keuangan yang sehat, namun sejak akhir tahun 2012 tugas dan wewenang Bapepam dalam mengatur dan mengawasi bursa efek indonesia telah dialihkan ke Otoritas Jasa Keuangan (OJK). Dengan demikian saat ini OJKlah yang berwenang untuk memberikan sanksi bagi emiten yang tidak mematuhi peraturan yang telah dibuatnya Adanya peraturan dan sanksi yang diberikan kepada emiten merupakan faktor yang dapat dijadikan indikator dalam menilai kepatuhan emiten.

Kasus pelanggaran peraturan yang terjadi selama tahun 2012-2014 muncul dalam berbagai bentuk terkait dengan keterbukan informasi, keterlambatan penyampaian laporan keuangan dan biaya pencatatan tahunan hingga adanya lonjakan harga saham yang sangat tinggi. Otoritas Jasa Keuangan sebenarnya telah memberikan saksi untuk menangani kasus-kasus diatas antara lain suspend yaitu diberhentikan sementara dari bursa akibat tidak memenuhi kewajiban yang telah ditetapkan oleh bursa, didelisting dari bursa yaitu dikeluarkan dari bursa, sanksi berupa surat peringatan tertulis apabila telat menyerahkan laporan keuangan selama 30 hari dari waktu yang telah ditentukan oleh bursa, sanksi denda sebesar Rp 50,000,000,- apabila telat menyerahkan laporan keuangan selama 60 hari dan sanksi denda sebesar Rp 150,000,000,- apabila telat menyerahkan laporan keuangan selama 90 hari, namun kasus yang muncul ternyata masih cukup besar meskipun dengan adanya sanksi. Besarnya frekuensi kasus yang terjadi akibat emiten di bursa masih belum menerapkan good corporate governance (prinsip tata kelola perusahaan yang baik). Tabel berikut akan memberikan gambaran secara lebih jelas jumlah kasus yang telah ditangani oleh bursa dan bapepam sepanjang tahun 2012-2014.

Tabel 1. Jenis sanksi dan frekuensi kemunculannya periode tahun 2012-2014

\begin{tabular}{llll}
\hline Jenis Sanksi & $\mathbf{2 0 1 2}$ & $\mathbf{2 0 1 3}$ & $\mathbf{2 0 1 4}$ \\
\hline Peringatan & 415 & 370 & 394 \\
Denda & 116 & 151 & 134 \\
Suspend & 18 & 18 & 18 \\
\hline
\end{tabular}

Sumber: data diolah, 2015

Otoritas Jasa Keuangan selalu berupaya agar penerapan good corporate governance dapat dilaksanakan di seluruh sektor perusahaan yang terdaftar di Bursa Efek Indonesia. Perusahaan yang telah melaksanakan good corporate governance diharapkan memiliki kinerja perusahaan yang baik pula, dimana hal ini dapat terlihat dari peningkatan harga sahamnya. Tinggi rendahnya harga saham sebuah perusahaan pada sektor tertentu merupakan indikator bagi investor untuk memperoleh keuntungan. Sepanjang 2012-2014 kinerja perusahaan hampir diseluruh sektor terus meningkat hal ini terlihat dari peningkatan harga sahamnya. Salah satunya penyebab meningkatnya harga saham adalah diadakannya PEMILU di tahun 2014, meskipun saat itu tingkat 
pertumbuhan ekonomi yang diukur dengan pendapatan domestik bruto cenderung melambat dari $6,2 \%$ pada tahun 2012 kemudian menjadi 5,2\% pada tahun 2014. Hal ini ternyata tidak menghambat kinerja perusahaan secara keseluruhan karena investor menganggap dengan adanya PEMILU terdapat sentimen positif, sehingga perlu direspon dengan positif pula. Hal itu terbukti dari 9 sektor yang berada dibursa hanya sektor pertambangan yang mengalami penurunan. Kondisi penurunan kinerja emiten dapat disebabkan adanya kebijakan pemerintah yang menerapakan larangan bagi emiten pertambangan batu bara untuk tidak melakukan ekspor, sehingga rata-rata emiten kehilangan pendapatnnya sebesar 30\%. Kerugian yang harus dialami oleh emiten pertambangan ini lah yang berpotensi menyebabkan perusahaan untuk lalai dalam menerapkan good corporate governance. Penelitian ini akan menganalisis tingkat kepatuhan emiten pertambangan pada tahun 2012-2014 dalam menerapkan good corporate governance melalui usia perusahaan, size perusahaan, pengungkapan dewan komisaris, komite audit, rapat dewan komisaris, rapat komite audit, kegiatan Corporate Social Responsibility, kegiatan sekretaris perusahaan, struktur kepemilikan saham dan ketepatan waktu dalam menyampaikan laporan keuangan perusahaan. Tabel berikut akan menjelaskan kinerja perusahaan di berbagai sektor di tahun 2012-2014.

Tabel 2. Kinerja perusahaan di seluruh sektor dari tahun 2012-2014

\begin{tabular}{lrrr}
\hline Indeks & \multicolumn{1}{c}{2012} & \multicolumn{1}{c}{2013} & \multicolumn{1}{c}{2014} \\
\hline AGRI & 2.041 & 2.108 & 2.328 \\
MINING & 1.857 & 1.418 & $1.360,5$ \\
Basic ind -Chem & 528 & 482 & 542.5 \\
Consumer & 1.574 & 2.047 & $2.158,5$ \\
Finance & 552 & 536 & 730.5 \\
Infrastructure & 903 & 876 & 1.156 \\
Manufacture & 1.147 & 1.151 & 1.326 .5 \\
Miscellanous & 1.327 & 1.199 & 1.295 .5 \\
Property & 324 & 449.5 & 522 \\
Trade & 737 & 772 & 868 \\
\hline Sumber: & & &
\end{tabular}

Sumber: dunia investasi

\section{B. LANDASAN TEORI}

Penerapan tata kelola perusahaan yang baik akan mendorong perusahaan untuk selalu mengungkapkan informasi dengan tepat waktu, akurat dan transparan. Pengungkapan informasi yang tepat waktu menunjukkan perusahaan mampu mengelola perusahaan dengan baik sehingga kinerja perusahaan pun meningkat. Peraturan bursa yang memuat mengenai penerapan good corporate governance tertuang dalam Keputusan Direksi PT Bursa Efek Jakarta Nomor: Kep-315/BEJ/062000 butir C mengenai board governance yang terdiri dari Komisaris Independen, Komite Audit dan Sekretaris Perusahaan. Dengan demikian penerapan tata kelola perusahaan pada perusahaan publik diharapkan dapat terlaksana dengan baik apabila perusahaan telah membentuk komite pengawas tersendiri seperti Komisaris Independen, Komite Audit dan Sekretaris Perusahaan yang bertugas untuk mengawasi kinerja dewan direksi dalam menjalankan operasional perusahaan secara efektif dan efisien dalam memaksimalkan nilai perusahaan. 
Penelitian terdahulu dilakukan oleh Budasari dan Ardiana (2014) menyatakan bahwa tingkat kesadaran emiten dalam mematuhi peraturan diperangaruhi oleh variabel usia, size, tendensi perataan laba dan kepemilikan publik pada tahun 2008-2012. Hasil penelitian menunjukkan perusahaan go public akan mematuhi peraturan pada level usia tertentu dan setelah melampaui level tertentu akan semakin tidak patuh dikarenakan saksi yang yang kurang tegas dan hanya berupa himbauan, sedangkan semakin besar size yang dilihat dari asset yang dikelola perusahaan maka perusahaan akan semakin patuh terhadap peraturan. Praktik perataan laba cenderung rendah untuk emiten yang memiliki tingkat kepatuhan yang tinggi terhadap peraturan dan kepemilikan sahamnya banyak dimiliki oleh publik dibandingkan hanya dimiliki oleh pihak tertentu.

Hasil penelitian Utari (2014) dalam Sujana (2015) menyatakan bahwa dewan komisaris perusahaan haruslah memiliki pengetahuan dan pengalaman di bidangnya agar dapat memberikan keputusan yang bijak. Pengetahuan dan pengalaman yang kurang di bidangnya juga diduga menjadi penyebab ukuran dewan komisaris tidak berpengaruh terhadap kinerja keuangan BPR. Penelitian yang dilakukan oleh Trihartati dan Pamudji (2010) mengungkapkan bahwa efektifitas komite audit dalam melaksanakan tugasnya diperusahaan tidak berdampak signifikan dalam proses pelaporan keuangan karena pembentukan komite audit hanya bersifat untuk memenuhi peraturan yang dibuat oleh BAPEPAM. Jadi perusahaan dengan komite audit yang telah menjalankan kegiatan rutinnya tidak menjamin perusahaan tersebut dapat menerapkan good corporate governance.

Penelitian yang dilakukan oleh Xie et al (2003) menyatakan bahwa ukuran dewan komisaris dan komite audit sebuah perusahaan berpengaruh dalam hal pengawasan untuk menghindari kecurangan yang dapat terjadi sehingga penerapan good corporate governance dapat terlaksana dengan baik. Semakin sering diadakan pertemuan baik oleh dewan komisaris maupun komite audit sebuah perusahaan maka proses pengawasan terhadap permasalahan perusahaan juga menjadi efektif dan kecurangan dapat dihindari.

Hasil penelitian Kristi Agatha (2013) mengungkapakan bahwa analisis corporate social responsibilty dapat dipengaruhi kepemilikan institusi, kepemilikan managerial dan kepemilikan publik sementara variabel yang terkait dengan pengungkapan informasi keuangan tidak berpengaruh terhadap pengungkapan CSR. Dengan demikian semakin patuh perusahaan terhadap aturan good corporate governance dalam mengungkapkan informasi keuangan sebuah perusahan tidak berdampak signifikan terhadap pelaporan kegiatan sosial perusahaan.

Penelitian yang dilakukan Khomsiyah (2005) dalam Hidayah (2008) menyatakan bahwa adanya hubungan good corporate governance dengan kualitas pengungkapan informasi. Perusahaan yang telah menerapkan good corporate governance seharusnya telah memenuhi asas transparansi, yang berarti telah menyediakan informasi dengan tepat waktu, jelas dan akurat. Dengan demikian perusahaan juga akan segera menyampaikan informasi keuangan perusahaan pada stakeholder untuk mempertanggungjwabkan kinerjanya dan mengungkapkan informasi yang diwajibkan oleh peraturan perundang-undangan yang tertuang dalam annual report. Hasil penelitian Rusdianti (2014) menyatakan bahwa kepemilikan saham oleh publik berpengaruh positif pada keptuhan emiten untuk menerapkan good corporate governance. Semakin tinggi presentase kepemilikan saham oleh publik dalam sebuah perusahaan akan meningkatkan jumlah pengawasan terhadap pihak manajemen oleh 
investor. Semakin banyaknya pengawasan terhadap pihak manajemen akan mendorong pihak manajemen untuk menerapkan aturan good corporate governance.

Penelitian Sundari (2012) menjelaskan penerapan prinsip-prinsip good corporate governance di PD BPR Sarimadu dengan metode deskriptif. Hasil penelitian menyatakan bahwa dengan mengungkapkan informasi secara tepat waktu, memadai, jelas dan akurat berarti perusahaan tersebut telah menerapkan aturan good corporate governance sehingga dapat menekan perilaku fraud yang mungkin timbul di PD BPR Sarimadu.

\section{METODE PENELITIAN}

\section{Jenis Penelitian, Populasi dan Sampel Penelitian}

Penelitian ini menggunakan metode analisis statistik deskriptif yang mengacu pada Keputusan Direksi PT Bursa Efek Jakarta Nomor: Kep-315/BEJ/062000 butir C mengenai board governance. Masalah-masalah yang berkaitan dengan penilaian kepatuhan emiten akan dianalisis dengan indikator tertentu yang telah dijelaskan subbab sebelumnya, sedangkan untuk menganalisis data yang telah dikumpulkan diperlukan adanya suatu kerangka yang jelas dalam menganalisis data sehingga dapat diketahui faktor-faktor yang mempengaruhi kepatuhan emiten disektor pertambangan dalam menerapkan good corporate governance.

Populasi pada penelitian ini adalah seluruh laporan tahunan perusahaan yang terdaftar di Bursa Efek Indonesia. Sampel pada penelitian ini adalah laporan tahunan perusahaan di sektor pertambangan pada tahun 2012-2014. Adapun perusahaan yang diteliti harus telah terdaftar di bursa minimal 1 tahun sebelum tahun dilakukan penelitian.

\section{Definisi Operasional}

1. Usia perusahaan merupakan informasi yang mengukur lama perusahaan telah terdaftar di bursa efek indonesia yang diukur dari selisih antara tahun penelitian dengan tahun saat perusahaan go public.

2. Size perusahaan merupakan informasi terkait jumlah aktiva yang dimiliki oleh perusahaan yang dijadikan sampel selama tahun penelitian.

3. Dewan komisaris merupakan jumlah anggota dewan komisaris baik komisaris independen maupun tidak.

4. Komite audit merupakan jumlah anggota komite audit yang bertanggung jawab pada perusahaan.

5. Rapat dewan komisaris merupakan informasi terkait jumlah rapat yang telah dilaksanakan anggota dewan komisaris dalam 1 tahun.

6. Rapat komite audit merupakan informasi terkait jumlah rapat yang telah dilaksanakan anggota komite audit dalam 1 tahun.

7. Corporate Sosial Responsibilty merupakan informasi terkait jumlah kegiatan CSR yang telah dilakukan perusahaan dalam 1 tahun.

8. Corporate Secretary merupakan informasi terkait jumlah kegiatan yang telah dilakukan sekretaris perusahaan dalam 1 tahun.

9. Kepemilikan saham merupakan informasi terkait persentase jumlah kepemilikan saham oleh publik.

10. Ketepatan waktu penyampaian laporan keuangan perusahaan merupakan informasi terkait jumlah emiten yang menyerahkan laporan keuangan perusahaan secara tepat waktu kepada bursa sesuai dengan peraturan yang telah ditetapkan. 


\section{Metode Pengumpulan Data}

Penelitian ini menggunakan data sekunder yaitu data laporan tahunan yang dilaporkan ke bursa efek indonesia mulai tahun 2012-2014. Laporan tahunan merupakan informasi yang wajib disampaikan oleh emiten sesuai dengan peraturan Bapepam-LK No.X.K.6 kepada stakeholder untuk mengambil keputusan berinvestasi dan menghindari adanya asimetri informasi. Informasi mengenai laporan tahunan dapat diakses melalui website resmi www. idx.com.

\section{E. HASIL DAN PEMBAHASAN}

Penelitian ini menggunakan sampel perusahaan-perusahaan di sektor pertambangan batu bara sejumlah 21 dari 508 emiten yang terdaftar dibursa efek indonesia, namun pada tahun 2012 sampel yang diteliti hanyalah sejumlah 17 emiten. Hal ini disebabkan emiten yang diteliti minimal harus telah listing di bursa selama 2 tahun agar kebijakan yang dikeluarkan layak untuk diteliti. Pada tahun 2013 emiten yang dilibatkan meningkat sejumlah dua emiten yakni PT Atlas Resources tbk dan Golden Energy Mines tbk sehingga total sampel menjadi 19 emiten, kemudian ditahun 2014 total sampel meningkat menjadi 21 karena ada dua emiten tambahan yang menjadi sampel yakni PT Baramultisuksessarana tbk dan Toba Bara Sejahtera tbk. Adapun rincian keseluruhan emiten yang digunakan sebagai sampel sebagai berikut:

Tabel 3. Emiten

\begin{tabular}{cl}
\hline No. & \multicolumn{1}{c}{ Nama Emiten } \\
\hline 1. & Adaro Energy, tbk (ADRO) \\
2. & Atlas Resources, tbk (ARII) \\
3. & ATPK Resources, tbk (ATPK) \\
4. & Borneo Lumbung Energy \& Metal, tbk (BORN) \\
5. & Berau Coal Energy, tbk (BRAU) \\
6. & Bumi Resources, tbk (BUMI) \\
7. & Bayan Resources, tbk (BYAN) \\
8. & Darma Henwa, tbk (DEWA) \\
9. & Delta Dunia Makmur, tbk (DOID) \\
10. & Golden Energy Mines, tbk (GEMS) \\
11. & Garda Tujuh Buana, tbk (GTBO) \\
12. & Harum Energy, tbk (HRUM) \\
13. & Indo Tambangraya Megah, tbk (ITMG) \\
14. & Resource Alam Indonesia, tbk (KKGI) \\
15. & Samindo Resources, tbk (MYOH) \\
16. & Perdana Karya Perkasa, tbk (PKPK) \\
17. & Tambang Batubara Bukit Asam, tbk (PTBA) \\
18. & Petrosea, tbk (PTRO) \\
19. & Golden Eagle Energy, tbk (SMMT) \\
20. & Bara Multi Suksesarana tbk (BSSR) \\
21. & Toba Bara Sejahtera tbk (TOBA) \\
\hline
\end{tabular}

Sumber :bursa efek Indonesia, 2015

Berdasarkan lamanya perusahaan pertambangan terdaftar di bursa dapat dibedakan menjadi perusahaan dengan usia go public dibawah umur rata-rata emiten dan perusahaan dengan usia go public diatas umur rata-rata emiten. 
Tabel 4. Usia emiten

\begin{tabular}{|c|c|c|c|}
\hline \multirow[t]{2}{*}{ Usia } & \multicolumn{3}{|c|}{ Jumlah } \\
\hline & 2012 & 2013 & 2014 \\
\hline Umur go public < rerata umur emiten-emiten & 10 & 12 & 14 \\
\hline Umur go public $\geq$ rerata umur emiten-emiten & 7 & 7 & 7 \\
\hline
\end{tabular}

Sumber: laporan tahunan emiten, 2015

Tidak berbeda dengan variabel usia maka variabel size perusahaan yang merujuk pada total asset yang dimiliki oleh perusahaan dapat dibedakan menjadi emiten berasset besar dan emiten berasset kecil.

Tabel 5. Size Emiten

\begin{tabular}{llll}
\hline Size & Jumlah & & \\
\cline { 2 - 4 } & 2012 & 2013 & 2014 \\
\hline Emiten bersize kecil & 12 & 13 & 15 \\
Emiten bersize besar & 5 & 6 & 6 \\
\hline
\end{tabular}

Sumber: laporan tahunan emiten, 2015

Emiten yang terdaftar di bursa paling lama sepanjang tahun 2012-2014 adalah PT Bumi Resources tbk dan PT Petrosea sementara emiten yang baru saja terdaftar dibursa pada tahun 2012 adalah PT Berau Coal Energy tbk dan PT Harum Energy tbk. Pada tahun 2013 dan 2014 jumlah emiten yang baru saja terdaftar dibursa masing-masing bertambah dua yaitu PT Atlas Resources tbk dan PT Golden Energy Mines tbk pada tahun 2013, kemudian di tahun 2014 emiten tambahan yang ikut diteliti adalah PT Baramulti Suksessarana tbk dan PT Toba Bara Sejahtera tbk. Berdasarkan jumlah asset atau aktiva yang dimiliki oleh perusahaan maka jumlah asset tertinggi dimiliki oleh PT Bumi resources tbk selama tahun 2012-2014 masing-masing sebesar $\$ 7,354$ juta; $\$$ 7,004 juta; \$ 6,501 juta, namun terdapat variasi pada kepemilikan asset terendah selama tahun penelitian. Jumlah asset terendah pada tahun 2012 dimiliki oleh PT ATPK Resources tbk \$ 16 juta, sedangkan pada tahun 2013 dan 2014 dimiliki oleh PT Perdana Karya Perkasa tbk masing-masing sebesar \$ 30 juta dan \$ 35 juta. Hasil penelitian menunjukkan bahwa perusahaan yang memiliki size besar cenderung lebih mematuhi good corporate governance dibandingkan perusahaan bersize kecil, hanya sebagian kecil dari perusahaan yang memiliki size besar terkena sanksi administratif dari bursa. Hal ini sesuai dengan penelitian Budasari dan Ardiana (2014). Demikian pula dengan usia, perusahaan yang telah lama terdaftar dibursa cenderung lebih patuh dibandingkan dengan perusaahan yang baru saja terdaftar dibursa. Hal ini terjadi karena perusahaan yang baru saja terdaftar di bursa belum terlalu disoroti oleh masyarakat, disamping itu berdasarkan data yang diteliti perusahaan yang baru terdaftar saham yang dimiliki publik rata-rata dibawah 50\% sehingga kurang ada rasa tanggung jawab untuk mengungkapkan informasi kepada publik, sehingga kewajiban mematuhi good corporate governance terabaikan.

Dewan komisaris merupakan pihak yang dipilih oleh para pemegang saham perusahaan untuk mengawasi kegiatan dewan direksi dalam mengelola perusahaan agar membuat keputusan secara obyektif demi kepentingan pemegang saham. Dewan komisaris yang terpilih terbagi menjadi dua yakni dewan komisaris independen maupun tidak. Semakin besar jumlah dewan komisaris independen yang direkrut oleh perusahaan maka semakin efektif pemantauan dewan direksi dalam pelaksanaan tugasnya yakni dalam memenuhi aturan good corporate governance. Sesuai dengan 
Surat Edaran Bapepam-LK No. SE-03/PM/2000 dan Peraturan BEI No. I-A menetapkan bahwa komposisi jumlah Komisaris Independen sekurang-kurangnya 30\% dari jajaran anggota Dewan Komisaris. Berdasarkan data dari tabel terbukti bahwa seluruh emiten telah melaporkan jumlah komisaris independen maupun komisaris perusahaan sesuai dengan aturan bursa, kecuali PT Borneo Lumbung Energy\&Metal, tbk yang hingga tahun 2015 belum menginformasikan mengenai jumlah komisaris yang dimilikinya serta PT Indo Tambangraya Megah, tbk yang komposisi jumlah dewan komisarisnya tidak sesuai dengan aturan bursa di tahun 2012. Hasil penelitian ini menunjukkan bahwa besaran komposisi dewan komisaris tidak mempengaruhi kepatuhan emiten terhadap aturan good corporate governance. Penelitian ini mendukung penelitian Utari (2014) dalam Sujana dkk (2015) yang menyatakan bahwa komposisi dewan komisaris tidak berpengaruh terhadap kinerja perusahaan. Dewan komisaris yang tidak berkompetensi dibidangnya dapat membuat keputusan yang dapat memperburuk kinerja perusahaan. Perusahaan yang memiliki kinerja buruk cenderung mengabaikan aturan good corporate governance dan sektor pertambangan sepanjang tahun 2012-2014 merupakan sektor dengan kinerja terburuk. Rincian data pengungkapan dewan komisaris oleh emiten selama tahun penelitian dijelaskan dalam tabel 6

Selama tahun penelitian jumlah komite audit yang dilaporkan oleh emiten ratarata sejumlah 3 orang yang terdiri dari 1 orang ketua komite dan 2 orang anggota. Hal ini sesuai dengan Keputusan Ketua Badan Pengawas Pasar Modal dan Lembaga Keuangan Nomor: KEP-643/BL/2012 tentang Pembentukan Dan Pedoman Pelaksanaan Kerja Komite Audit, namun hasil penelitian menunjukkan bahwa besar kecilnya jumlah komite audit yang terbentuk tidak berpengaruh pada kepatuhan emiten untuk menerapkan good corporate governance terbukti dengan banyaknya emiten yang masih mendapatkan sanksi akibat terlambat melaporkan laporan keuangan. Peran komite audit dalam mewujudkan good corporate governance yakni dengan mengawasi proses penyusunan dan pelaporan laporan keuangan yang dapat dipertanggungjawabkan dan tepat waktu sesuai aturan bursa. Penurunan kondisi kinerja emiten disektor pertambangan selama tahun penelitian menyebabkan peran komite audit dalam mengontrol laporan keuangan menjadi tidak maksimal sehingga timbulah sanksi. Penelitian ini mendukung penelitian Pamudji dan Trihartati (2010) yang menyatakan bahwa pembentukan komite audit dalam perusahaan hanya bersifat mandatory terhadap peraturan yang ada. Hal tersebut menyebabkan komite audit belum melaksanakan tugas dan tanggung jawabnya secara maksimal sehingga fungsi dan perannya tidak efektif. Ada kemungkinan bahwa pertemuan komite audit jarang dihadiri baik oleh pihak manajemen maupun oleh auditor ekstemal. Sehingga, masalah-masalah yang terdapat dalam proses laporan keuangan tidak terungkap. 
Tabel 6. Jumlah Dewan Komisaris Emiten

\begin{tabular}{|c|c|c|c|c|c|c|}
\hline \multirow{3}{*}{$\begin{array}{c}\text { Nama } \\
\text { Emiten }\end{array}$} & \multicolumn{6}{|c|}{ Jumlah } \\
\hline & \multicolumn{2}{|c|}{2012} & \multicolumn{2}{|c|}{2013} & \multicolumn{2}{|c|}{2014} \\
\hline & $\begin{array}{l}\text { Komisaris } \\
\text { perusahaan }\end{array}$ & $\begin{array}{l}\text { Komisaris } \\
\text { independen }\end{array}$ & $\begin{array}{l}\text { Komisaris } \\
\text { perusahaan }\end{array}$ & $\begin{array}{c}\text { Komisaris } \\
\text { independen }\end{array}$ & $\begin{array}{c}\text { Komisaris } \\
\text { perusahaan }\end{array}$ & $\begin{array}{l}\text { Komisaris } \\
\text { independen }\end{array}$ \\
\hline ADRO & 4 & 2 & 3 & 2 & 3 & 2 \\
\hline BORN & 2 & 3 & 2 & 1 & - & - \\
\hline BUMI & 9 & 4 & 3 & 4 & 3 & 4 \\
\hline ARII & & & 4 & 2 & 4 & 2 \\
\hline ATPK & 2 & 1 & 2 & 1 & 2 & 1 \\
\hline BRAU & 5 & 3 & 5 & 3 & 2 & 2 \\
\hline BYAN & 3 & 2 & 4 & 2 & 3 & 2 \\
\hline DEWA & 2 & 1 & 3 & 1 & 3 & 2 \\
\hline DOID & 4 & 4 & 4 & 4 & 2 & 4 \\
\hline GEMS & & & 2 & 3 & 3 & 2 \\
\hline GTBO & 2 & 1 & 2 & 1 & 2 & 1 \\
\hline ITMG & 5 & 1 & 4 & 2 & 4 & 2 \\
\hline KKGI & 3 & 2 & 3 & 2 & 3 & 2 \\
\hline MYOH & 2 & 1 & 2 & 1 & 2 & 1 \\
\hline PKPK & 2 & 1 & 2 & 1 & 2 & 1 \\
\hline PTBA & 4 & 2 & 3 & 3 & 4 & 2 \\
\hline PTRO & 4 & 3 & 4 & 3 & 3 & 2 \\
\hline SMMT & 2 & 3 & 2 & 3 & 2 & 1 \\
\hline BSSR & & & & & 5 & 2 \\
\hline TOBA & & & & & 1 & 2 \\
\hline HRUM & 3 & 2 & 3 & 2 & 3 & 2 \\
\hline
\end{tabular}

Berikut ini tabel rincian jumlah rapat dewan komisaris dan jumlah rapat komite audit yang telah dilakukan selama tahun penelitian.

Tabel 7. Rapat Dewan Komisaris Audit

\begin{tabular}{cccc}
\hline \multirow{2}{*}{ Nama Emiten } & \multicolumn{3}{c}{$\begin{array}{c}\text { Jumlah Rapat D. } \\
\text { Komisaris }\end{array}$} \\
& 2012 & 2013 & 2014 \\
\hline ADRO & 4 & 3 & 4 \\
BORN & $3^{*}$ & $2^{*}$ & $-*$ \\
BUMI & $2^{*}$ & $5^{*}$ & $3^{*}$ \\
ARII & & $8^{*}$ & $6^{*}$ \\
ATPK & $4^{*}$ & 1 & 3 \\
BRAU & $5^{*}$ & $6^{*}$ & $-*$ \\
BYAN & $4^{*}$ & 2 & 2 \\
DEWA & 5 & 5 & 8 \\
DOID & $-*$ & 2 & $4 *$ \\
GEMS & & 4 & 5 \\
GTBO & $3 *$ & $3 *$ & $-*$ \\
ITMG & 13 & 15 & 15 \\
KKGI & $7 *$ & 7 & 4 \\
MYOH & 8 & 9 & 5 \\
PKPK & $3 *$ & $3 *$ & $3 *$ \\
PTBA & 12 & 13 & 12 \\
PTRO & 2 & 2 & 7 \\
SMMT & $-*$ & $-*$ & $-*$ \\
BSSR & & & 2 \\
TOBA & & & 6 \\
HRUM & 3 & 2 & 2 \\
\hline
\end{tabular}

Tabel 8. Rapat Komite Audit

\begin{tabular}{|c|c|c|c|}
\hline \multirow[t]{2}{*}{ Nama Emiten } & \multicolumn{3}{|c|}{$\begin{array}{c}\text { Jumlah Rapat D. } \\
\text { Komisaris }\end{array}$} \\
\hline & 2012 & 2013 & 2014 \\
\hline ADRO & 23 & 24 & 24 \\
\hline BORN & $4^{*}$ & $6^{*}$ & _* \\
\hline BUMI & $7 *$ & $11 *$ & $8^{*}$ \\
\hline ARII & & $5^{*}$ & $4 *$ \\
\hline ATPK & $4 *$ & 4 & 4 \\
\hline BRAU & $5^{*}$ & $12 *$ & ${ }^{*}$ \\
\hline BYAN & $8^{*}$ & 8 & 8 \\
\hline DEWA & 9 & 12 & 11 \\
\hline DOID & $8^{*}$ & 12 & _* \\
\hline GEMS & & 6 & 5 \\
\hline GTBO & $4 *$ & $4 *$ & $4 *$ \\
\hline ITMG & 12 & 12 & 12 \\
\hline KKGI & $6^{*}$ & 6 & 5 \\
\hline MYOH & 3 & 4 & 5 \\
\hline PKPK & $4 *$ & $4 *$ & $3 *$ \\
\hline PTBA & 48 & 57 & 59 \\
\hline PTRO & 4 & 4 & 4 \\
\hline SMMT & $-*$ & ${ }^{*}$ & $4 *$ \\
\hline BSSR & & & - \\
\hline TOBA & & & 9 \\
\hline HRUM & 5 & 5 & 5 \\
\hline
\end{tabular}

Sumber: Laporan tahunan emiten 
Berdasarkan data tahun 2012 dari 17 emiten hanya 11,76\% yang tidak mengungkapkan informasi terkait jumlah rapat dewan komisaris. Jumlah emiten ditahun 2012 yang melakukan jumlah rapat diatas rata-rata berkisar $35.29 \%$ emiten, sementara jumlah emiten yang terkena sanksi ditahun tersebut sejumlah $58.81 \%$ dan rata-rata didominasi emiten dengan frekuensi rapat dibawah rata-rata. Pada tahun 2013 dari 19 emiten hanya $5.26 \%$ yang tidak mengungkapkan informasi terkait jumlah rapat dewan komisaris. Jumlah emiten di tahun 2013 yang melakukan rapat diatas rata-rata bertambah sebesar $42.11 \%$, sementara jumlah emiten yang terkena sanksi ditahun tersebut sejumlah $42.10 \%$ dan rata-rata didominasi emiten dengan frekuensi rapat dibawah rata-rata. Pada tahun 2014 dari 21 emiten hanya 19.04\% yang tidak mengungkapkan informasi terkait frekuensi rapat dewan komisaris. Jumlah emiten di tahun 2014 yang melakukan rapat diatas rata-rata berkisar $52.38 \%$, sementara jumlah emiten yang terkena sanksi ditahun tersebut sejumlah $39.09 \%$ yang didominasi frekuensi rapatnya dibawah rata-rata. Rendahnya frekuensi rapat dewan komisaris menunjukkan semakin tidak efektif kegiatan pengawasan dalam mematuhi aturan good corporate governance. Hasil penelitian ini mendukung temuan yang dilakukan oleh Xie et al (2003) menyatakan bahwa semakin sering dewan komisaris mengadakan rapat maka fungsi pengawasan manajemen perusahaan semakin efektif karena probabilitas perusahaan menerapkan aturan good corporate governance juga semakin besar. Jumlah rapat yamg dilakukan komisaris dijelaskan melalui tabel 7 (tujuh)

Selama tahun 2012-2013 hanya 1 perusahaan saja yang tidak menginformasikan mengenai jumlah rapat komite audit yaitu PT Golden Eagle Energy, namun di tahun 2014 jumlah emiten yang tidak melaporkan informasi tersebut meningkat menjadi 4 perusahaan yaitu PT Borneo Lumbung Energy\&Metal, PT Berau Coal Energy, PT Delta Dunia Makmur dan PT Baramulti Suksessarana. Berdasarkan aturan BAPEPAM terkait frekuensi rapat komite audit dalam setahun yaitu peraturan IX.I.5 tentang Pembentukan dan Pedoman Pelaksanaan Kerja Komite Audit, Lampiran Keputusan Ketua Bapepam nomor Kep-29/PM/2004 tertanggal 24 September 2004 Komite Audit setidaknya melakukan rapat sebanyak 4 kali dalam satu tahun. Berdasarkan penelitian ini frekuensi jumlah rapat komite audit ternyata tidak mempengaruhi penerapan emiten dalam mematuhi aturan good corporate governance. Jadi besar kecilnya frekuensi rapat yang dilakukan oleh komite audit tidak mempengaruhi emiten dalam menunjukan kepatuhannya terhadap aturan good corporate governance terbukti dari 10 emiten ditahun 2012 yang mendapatkan sanksi, 9 emiten telah melakukan frekuensi rapat diatas rata-rata demikian pula yang terjadi ditahun 2013-2014. Hal ini mendukung penelitian dari Pamudji dan Trihartati (2010) yang menyatakan bahwa kegiatan yang dilakukan oleh komite audit termasuk rapat rutin yang dilakukan dalam perusahaan hanya bersifat mandatory terhadap peraturan yang ada. Karena bersifat pemenuhan aturan pada BAPEPAM kegiatan menangani permasalahan pada laporan keuangan juga menjadi tidak maksimal.

Berikut ini tabel rincian pengungkapan kegiatan corporate social responsibility (CSR) dan sekretaris perusahaan yang telah dilakukan emiten selama tahun penelitian. 
Tabel 9. Corporate Social Responsibility Emiten

\begin{tabular}{lccc}
\hline Nama Emiten & \multicolumn{3}{c}{ Kegiatan CSR } \\
& 2012 & 2013 & 2014 \\
\hline ADRO & 9 & 9 & 11 \\
BORN & $11^{*}$ & $32^{*}$ & $-*$ \\
BUMI & $14^{*}$ & 40 & $145^{*}$ \\
ARII & & $13^{*}$ & $15^{*}$ \\
ATPK & $4^{*}$ & 2 & 5 \\
BRAU & $13^{*}$ & $15^{*}$ & $69^{*}$ \\
BYAN & $7^{*}$ & 41 & 28 \\
DEWA & 48 & 109 & 70 \\
DOID & $13^{*}$ & 14 & $53^{*}$ \\
GEMS & & 17 & 34 \\
GTBO & $3^{*}$ & $2^{*}$ & $-*$ \\
ITMG & 25 & 12 & 35 \\
KKGI & $42^{*}$ & 60 & 52 \\
MYOH & 13 & 73 & 71 \\
PKPK & $-*$ & $-*$ & $-*$ \\
PTBA & 16 & 14 & 35 \\
PTRO & 17 & 19 & 21 \\
SMMT & $15^{*}$ & $12^{*}$ & $107^{*}$ \\
BSSR & & & 133 \\
TOBA & & & 54 \\
HRUM & 9 & 37 & 42 \\
\hline
\end{tabular}

Tabel 10. Corporate Secretary Emiten

\begin{tabular}{|c|c|c|c|}
\hline \multirow{2}{*}{$\begin{array}{l}\text { Nama } \\
\text { Emiten }\end{array}$} & \multicolumn{3}{|c|}{ Kegiatan Sekretaris Perusahaan } \\
\hline & 2012 & 2013 & 2014 \\
\hline ADRO & 59 & 76 & 70 \\
\hline BORN & $11 *$ & $11 *$ & _* \\
\hline BUMI & $183^{*}$ & $139 *$ & $89 *$ \\
\hline ARII & & $94 *$ & $74^{*}$ \\
\hline ATPK & $13^{*}$ & 17 & 15 \\
\hline BRAU & $44 *$ & $15^{*}$ & $14^{*}$ \\
\hline BYAN & $59 *$ & 4 & 6 \\
\hline DEWA & 16 & 65 & 55 \\
\hline DOID & _* & 4 & $6^{*}$ \\
\hline GEMS & & - & 10 \\
\hline GTBO & _* & - * & $9 *$ \\
\hline ITMG & 10 & 15 & 18 \\
\hline KKGI & $5 *$ & 4 & 8 \\
\hline MYOH & 4 & 4 & 13 \\
\hline PKPK & - * & - & $3 *$ \\
\hline PTBA & $\overline{5} 2$ & 163 & 147 \\
\hline PTRO & 20 & - & 40 \\
\hline SMMT & $2 *$ & $2 *$ & $14^{*}$ \\
\hline BSSR & & & 4 \\
\hline TOBA & & & 52 \\
\hline HRUM & 21 & 49 & 61 \\
\hline
\end{tabular}

Sumber: laporan tahunan emiten

Tanggung jawab sosial perusahaan merupakan salah satu kegiatan yang harus dilaksanakan oleh perusahaan untuk meningkatkan nilai perusahaan, semakin besar pengungkapan tanggung jawab sosial perusahaan (CSR) yang dilakukan menunjukkan bahwa emiten patuh terhadap aturan good corporate governance. Berdasarkan analisis data selama tahun penelitian banyak sedikitnya jumlah pengungkapan kegiatan CSR tidak mempengaruhi kepatuhan emiten dalam menerapkan aturan good corporate governance. Hal ini terlihat pada tabel 1.8 pada tahun 2012, 2013 dan 2014 sejumlah $42.85 \%, 58 \%$ dan $61 \%$ emiten yang patuh terhadap aturan board governance cenderung mengungkapkan kegiatan CSRnya dibawah rata-rata. Hasil penelitian ini mendukung penelitian yang dilakukan Agatha (2013) Pengungkapan corporate social responsibility tidak berdampak secara signifikan pada penerapan good corporate governance, hal ini disebabkan perusahaan patuh terhadap aturan good corporate governance dengan mengungkapkan informasi keuangan secara tepat waktu belum tentu lebih banyak melakukan aktivitas sosial karena perusahaan lebih berorientasi pada laba semata. Manajemen lebih tertarik untuk memfokuskan pengungkapan informasi keuangan saja dan menganggap tidak perlu melaporkan hal-hal yang dapat mengganggu informasi keuangan perusahaan seperti laporan tanggung jawab sosial.

Corporate secretary merupakan pihak yang bertugas memastikan transparansi, akuntabilitas, tanggung jawab dan independensi perusahaan dengan mengungkapkan berbagai informasi terkait perusahaan yang bermanfaat bagi investor sebagai dasar pengambilan keputusan. Semakin sering corporate secretary emiten mengungkapkan informasi terkait kegiatannya maka semakin banyak informasi yang diungkapkan kepublik, dengan demikian emiten telah mematuhi aturan good corporate governance. Jika emiten jarang memberikan informasi kepada investor berarti pihak corporate secretary tidak menjalankan tugasnya sesuai aturan, dengan demikian investor akan memiliki sentimen negatif kepada emiten yang dapat berdampak pada menurunnya nilai perusahaan dan kepatuhan emiten mematuhi good corporate governance. Berdasarkan analisis data menunjukkan bahwa pengungkapan kegiatan corporate secretary ternyata 
berpengaruh kepada kepatuhan emiten dalam menerapkan good corporate governance. Rata-rata emiten yang terkena sanksi frekuensi pengungkapannya relatif rendah. Tabel 1.9 menjelaskan jumlah kegiatan corporate secretary masing-masing emiten selama tahun penelitian. Hasil penelitian ini mendukung Khomsiyah (2005) dalam Hidayah (2008) bahwa kegiatan pengungkapan informasi dalam rangka menerapkan good corporate governance memang memiliki pengaruh secara signifikan. Semakin besar pengungkapan informasi yang dilakukan menujukan bahwa emiten tersebut semakin patuh dalam menerapkan good corporate governance.

Kepemilikan saham oleh publik merupakan salah satu indikator yang mendorong emiten untuk patuh terhadap aturan good corporate governance karena semakin banyak saham yang dimiliki oleh publik maka investor yang menjadi pemilik saham adalah masyarakat. Dengan demikian emiten akan semakin bertanggung jawab untuk mengungkapkan informasi kepada masyarakat sehingga dapat meningkatkan kepatuhan emiten terhadap aturan good corporate governance. Berdasarkan analisis data rata-rata jumlah saham emiten yang dimiliki oleh publik selama tahun penelitian berada dikisaran kurang dari 50\%, hal ini sangat berpengaruh terhadap kepatuhan emiten dalam menerapkan good corporate governance. Dengan demikian semakin sedikit jumlah saham yang dimiliki oleh publik maka emiten akan semakin tidak patuh terhadap aturan good corporate governance, terbukti selama tahun penelitian rata-rata emiten yang terkena sanksi jumlah saham yang dimiliki publik sebesar dibawah 50\%. Hasil penelitian ini mendukung Rusdianti (2014).

Tabel 10. Proporsi kepemilakan saham emiten oleh publik

\begin{tabular}{llll}
\hline Nama Emiten & \multicolumn{3}{l}{ Kepemilikan Saham Publik } \\
\cline { 2 - 4 } & 2012 & 2013 & 2014 \\
\hline ADRO & $49.91 \%$ & $35.26 \%$ & $35.23 \%$ \\
BORN & $35.34 \%^{*}$ & $39.27 \%^{*}$ & $-*$ \\
BUMI & $60.51 \%^{*}$ & $59.69 \%^{*}$ & $59.69 \%^{*}$ \\
ARII & & $30.31 \%^{*}$ & $31.26 \%^{*}$ \\
ATPK & $26.91 \%^{*}$ & $11.02 \%$ & $11.05 \%$ \\
BRAU & $11.87 \%^{*}$ & $15.26 \% *$ & $15.26 \% *$ \\
BYAN & $9.47 \%^{*}$ & $12.45 \%$ & $12.45 \%$ \\
DEWA & $60.93 \%$ & $60.71 \%$ & $60.71 \%$ \\
DOID & $60.04 \%^{*}$ & $60.3 \%$ & $60 \%^{*}$ \\
GEMS & & $3 \%$ & $3 \%$ \\
GTBO & $40.2 \% *$ & $39.91 \% *$ & $2.24 \% *$ \\
ITMG & $34.99 \%$ & $35 \%$ & $35 \%$ \\
KKGI & $37.1 \% *$ & $36.78 \%$ & 35.14 \\
MYOH & $21.86 \%$ & $25.77 \%$ & $25.77 \%$ \\
PKPK & $-*$ & $-*$ & $45.98 \% *$ \\
PTBA & $16.19 \%$ & $16.28 \%$ & $15.28 \%$ \\
PTRO & $30.20 \%$ & $22.28 \%$ & $30.20 \%$ \\
SMMT & $18.35^{*}$ & $16.53 \% *$ & $28.48 \% *$ \\
BSSR & & & $8.89 \%$ \\
TOBA & & & $12.5 \%$ \\
HRUM & $29.51 \%$ & $29.27 \%$ & $29.21 \%$ \\
\hline
\end{tabular}

*) terkena sanksi

Sumber: laporan tahunan emiten 
Ketepatan waktu pelaporan juga merupakan indikator untuk melihat kepatuhan emiten terhadap bursa karena terkait sanksi maupun denda yang diberikan pada emiten bila terlambat untuk melaporkan laporan keuangan tahunannya. Jika emiten melaporkan laporan keuangan auditnya secara tepat waktu dengan demikian emiten tersebut patuh pada aturan good corporate governance. Menurut keputusan ketua BAPEPAM LK No. KEP 346/BL/2011 Laporan keuangan tahunan wajib disampaikan kepada Bapepam dan LK dan diumumkan kepada masyarakat paling lambat pada akhir bulan ketiga setelah tanggal laporan keuangan tahunan. Sepanjang tahun penelitian yakni mulai tahun 2012 terdapat 10 emiten yang terlambat dalam melaporkan laporan keuangan tahunanya, kemudian ditahun 2013 terdapat 7 emiten yang terlambat dan di tahun 2014 emiten yang melaporkan keterlambatan penyampaian laporan keuangan meningkat menjadi 8 emiten. Sejumlah emiten yang telah dilaporkan terlambat mengungkapkan laporan keuangan tahunanya ditahun 2014 yakni 7 emiten bahkan berturut-turut telah terlambat melaporkan laporan keuangannya selama tahun penelitian Dengan demikian semakin terlambat sebuah emiten dalam melaporakan laporan keuangan tahunannya maka probabilitas emiten tersebut untuk menerapkan good corporate governance semakin rendah. Hasil penelitian ini mendukung penelitian Sundari (2012).

\section{E. PENUTUP}

Berdasarkan hasil analisis dan pembahasan penelitian, maka dapat disimpulkan beberapa hal. Pertama, perusahaan yang memiliki size besar cenderung lebih mematuhi good corporate governance dibandingkan perusahaan bersize kecil, hanya sebagian kecil dari perusahaan yang memiliki size besar terkena sanksi administratif dari bursa. Perusahaan yang telah lama terdaftar dibursa cenderung lebih patuh dibandingkan dengan perusaahan yang baru saja terdaftar dibursa. Besaran komposisi dewan komisaris tidak mempengaruhi kepatuhan emiten terhadap aturan good corporate governance. Kedua, Besar kecilnya jumlah komite audit yang terbentuk tidak berpengaruh pada kepatuhan emiten untuk menerapkan good corporate governance terbukti dengan banyaknya emiten yang masih mendapatkan sanksi akibat terlambat melaporkan laporan keuangan. Semakin tinggi frekuensi rapat dewan komisaris berpengaruh semakin efektif kegiatan pengawasan dalam penerapan aturan good corporate governance.

Selain itu, besar kecilnya frekuensi rapat yang dilakukan oleh komite audit tidak mempengaruhi emiten dalam menunjukan kepatuhannya terhadap aturan good corporate governance. Banyak sedikitnya jumlah pengungkapan kegiatan CSR tidak mempengaruhi kepatuhan emiten dalam menerapkan aturan good corporate governance. Selain itu, pengungkapan kegiatan corporate secretary ternyata berpengaruh kepada kepatuhan emiten dalam menerapkan good corporate governance. Kepemilikan saham oleh publik berpengaruh terhadap kepatuhan emiten dalam menerapkan good corporate governance. Ketepatan waktu perusahaan dalam melaporkan laporan keuangannya berpengaruh positif pada penerapan good corporate governance. 


\section{DAFTAR PUSTAKA}

Budasari dan Ardiana. 2014. Faktor-Faktor Yang Mempengaruhi Perusahaan Publik Menerapkan Aturan Board Governance Di Indonesia. E-jurnal Akuntansi Universitas Udayana 8.1. 274-290

Mujati, Y. \& Meida, D., 2016. Pengaruh Earning Per Share Dan Price Earning Ratio Terhadap Debt To Equity Ratio Dan Harga Saham Pada Perusahaan Sektor Makanan Dan Minuman Di Bursa Efek Indonesia. Eksis: Jurnal Riset Ekonomi dan Bisnis, April, Volume 11, pp. 102-123

Mufidah, E. 2017. Analisis Laba, Arus Kas Operasi dan Nilai Buku Ekuitas Terhadap Harga Saham. Jurnal Riset Ekonomi dan Bisnis EKSIS, Vol. 12 No. 1

Hidayah, E. 2008. Pengaruh Kualitas Pengungkapan Informasi Terhadap Hubungan Antara Penerapan Corporate Governance dengan Kinerja Perusahaan di Bursa Efek Jakarta. JAAI, Vol 12 No.1. 53-64

Kristi, A. 2013. Faktor-Faktor yang Mempengaruhi Pengungkapan Corporate Social Responsibility Pada Perusahaan Publik di Indonesia. Jurnal Ilmiah Mahasiswa FEB

Pamudji dan Trihartati. 2010. Pengaruh Independensi dan Efektivitas Komite Audit Terhadap Manajemen Laba. Jurnal Dinamika Akuntansi, Vol 2 No.1. 21-29

Rusdianti, R. 2014. Pengaruh Corporate Governance dan Karakteristik Perusahaan Terhadap Ketepatan Waktu Pelaporan Perusahaan di Internet. E- Journal Unesa

Sujana. 2015. Pengaruh Mekanisme Good Corporate Governance Terhadap Kinerja Keuangan Bank Perkreditan Rakyat Di Bali. E-journal Akuntansi Universitas Pendidikan Ganesha, Vol 3 No.1

Sundari, H. 2012. Evaluasi Penerapan Good Corporate Governance Pada Bank PD BPR Sarimadu. Jurnal Sorot, Vol. 9 No.1

Xie, B. dan W.N. Davidson III, dan P1. Dadalt. 2003. Earnings Management and Corporate Governance: The Role of Board and The Audit Committee. Journal of Corporate Finance, Vol. 9 No. 3, 295-316 